\title{
Indonesian Learning Culture Based On Android
}

\author{
Ribka Kowi ${ }^{1}$, Tri Wahyu Widyaningsih, S.Kom.,MMSI ${ }^{2}$ \\ Tanri Abeng University, Informatics Engineering, Jakarta, Indonesia \\ Accepted on February $26^{\text {th }}, 2017$ \\ Approved on June $5^{\text {th }}, 2017$
}

\begin{abstract}
Indonesia is the fourth country with the largest population in the world and rich of cultural heritage and local wisdom. However, the majority of Indonesian people are less caring, less knowing and minimum understanding about Indonesian culture because of the lack of facilities to provide information of Indonesian culture. On the other hand, Android development is increasingly rapid and free to develop. This is an opportunity that can be used to build a culture of learning systems to maintain the existence Indonesia culture in the eyes of Indonesian people.
\end{abstract}

This research aims to create a system of Indonesian Culture Learning android based mobile application that can be used as a medium of learning Indonesian culture. The methodology of this development is using SDLC which starting from planning, requirements analysis, system design, implementation, testing and maintenance. And using Android Studio as the main program, Photoshop and Microsoft Paint for image processing, and DIA to design UML.

Indonesian Learning Culture can display ten kinds of culture, that is: traditional house, traditional food, traditional clothes, traditional dance, traditional language, traditional music instruments, traditional song, tribe, handy craft and tourist attraction. Where each category shows an example of each of the provinces in Indonesia.

Keyword- Android, Indonesian Culture, Mobile Application, SDLC.

\section{OVERVIEW}

Indonesia is an archipelago with diverse races and cultures starting from Sabang to Merauke. This is the only wealth can never be purchased by other countries. Society of Indonesia himself was very aware of all wealth owned, but do they know well the culture that exists in this beloved country? The answer is no, why? According to Amna Shifia and friends (2014:1) this is caused by the negative influence of the development of the current globalization has led to the development of the cultural influence of the nation of Indonesia. Besides that the lack of facilities provided by the government may also affect the waning values of cultural preservation.
And according to Dyina Shoful dan Heri Sismoro (2015:1) stated that the impact of globalization is also, lead to changes in lifestyle a more modern society. The effect is people will prefer to the new culture that may be considered more practical than the local culture. Besides that our young generation have also felt this changing of lifestyle, they who simply absorb foreign cultures that are considered more modern for example, an irreverent way of dressing and how to get along too freely adopted by teenagers causing a defiance of the existing norms.

According to Amna Shifia and friends (2014:1) they declare that another factor is the problem is the lack of public awareness of the importance role of the local culture. The local culture is the identity of the nation. As the nation's identity, the local culture should be kept maintained the authenticity or ownership so as not to be recognized by other countries. However, it does not cover the possibility of incoming foreign culture as long as it complies with the personality of the country because the country also need input-input from other countries that will have an effect on developments in his country [3].

Even so, the issue can be resolved by performing a good introduction through effective and efficient media, one of them using a mobile application that contains about the culture of Indonesia. The mobile application is the right solution to solve existing problems, as it can make it easier for everybody especially the young generation in the study of art and culture.

Indonesian young generation and the community are the target of creating this application. At certain of time like now days most of smartphone users are student ranging from elementary school until college. In addition, mobile applications can also be utilized as a means to introduce the culture and natural beauty to tourists Broad.

The objectives to be achieved are as follows:

1. Introducing Indonesian culture and arts in interesting ways.

2. Increasing Indonesian people's interest to learn Indonesian culture and arts.

3. Adding alternate media to learn about Indonesian culture besides books. 
4. Created a media learning about Indonesia culture that can help the process of teaching and learning activities.

Based on the background that has been covered then the author are motivated to make Indonesia Culture based on android set on history, culture and the arts of Indonesia. This learning media also comes with questions and assessment exercise to test the knowledge of the users of the application. So it is expected to provide the solution of existing problems.

\section{RESEARCH METHODOLOGY}

This method starts with collecting data, analyzing the data and interpret it. Descriptive methods in the implementation conducted through a survey techniques, case studies, analysis of behavior, the study of time and motion and analysis of the documentary".

\subsection{Data Collection Technique}

This research used questionnaire technique to collect data from respondents. In addition spreading questionnaires in process of collecting data, researchers also take advantage of smart phones as a medium to access applications that have been created to expedite data collection process. The questionnaire will be used to assess the applications, while smartphone as a medium so that the respondent can see and assess the applications that already installed.

\subsubsection{Types of Data}

The data collected in this study is qualitative and quantitative data, which are:

a. Qualitative data is data about the development process of learning media in the form of criticism and suggestions from respondents

b. Quantitative data is the core data in the study is data feasibility assessment developed learning media.

\subsubsection{Technique Analysis Data}

Data and information that has been obtained and analysed, the data will be analysed in this study are as follows:

1. Qualitative Data

Qualitative data in the form of criticism and suggestions provided by respondents will be analysed descriptively.

2. Quantitative Data

The quantitative data obtained from questionnaires assessing the quality of products provided to the respondent. Data quality learning media in the form of qualitative data. To get a quality assessment media, the qualitative data were analyzed with the following steps:
Then search for the ideal score (ideal value) to determine the

Table 1. Score scale rating

\begin{tabular}{|l|c|}
\hline \multicolumn{1}{|c|}{ Answer Scale } & Score \\
\hline Yes/Attractive/Fast/Good/Easy/Helpful/Agree & 4 \\
\hline $\begin{array}{l}\text { Quite interest/Fast enough/Quite easy/less } \\
\text { agree }\end{array}$ & 3 \\
\hline Unattractive/Less fast/Difficult/Neutral & 2 \\
\hline $\begin{array}{l}\text { No/Not attractive/Very Slow/Bad/ Very } \\
\text { Disagree }\end{array}$ & 1 \\
\hline
\end{tabular}

scale and the total answer. To search for the ideal score of all items, use the following formula:

Ideal value $=$ Scale value $\mathrm{x}$ Number of respondents

Next will be determined the rating scale value and the intervals between 0 - 100 values.

Table 2. Interval and Category

\begin{tabular}{|c|c|}
\hline Interval & Category \\
\hline $0 \%-24,99 \%$ & Very Weak \\
\hline $25 \%-49,99 \%$ & Weak \\
\hline $50 \%-74,99 \%$ & Strong Enough \\
\hline $75 \%-99,99 \%$ & Strong \\
\hline $100 \%$ & Very Strong \\
\hline
\end{tabular}

After that, to determine the number of answers from the respondents by percentage using the following formula:

$$
\begin{array}{|l|l|}
\hline p=\frac{f}{n} \times 100 \% & \text { Information: } \\
& \mathrm{p}=\text { Percentage } \\
\mathrm{f}=\text { Frequency of each questionnaire } \\
\mathrm{n}=\text { number of ideal score }
\end{array}
$$

\subsection{Place And Research Time}

Researchers conducted the study at Tanri Abeng University at Swadarma Raya St. No. 58, Ulujami Pesanggrahan, South Jakarta. Research conducted in stages in November 2016. 


\subsection{Systems Development Methods}

The development of the system of learning the Indonesia culture based on android using System Development Lifecycle (SDLC) model. The SDLC model is a systematic approach to software and sequential, beginning from the stage of the System planning, analysis, design, implementation, testing and maintenance. Indonesia learning culture is concerned with activities such as:

\section{System Planning}

After problem that occurred in community are found, researcher decide to solve that problem by creating a learning culture system that expected to resolve problem that occurs. This are the planning to create the system:

- Define the goal of developing the system, the system should be able to help resolve problems that occur and useful to users and the determination of the scope of the development of the system that is the target or targets of the system constructed in this case the main target of cultural learning systems to the entire people of Indonesia.

- $\quad$ Feasibility study, namely a feasibility study for the system to be made, such as making a study of how business processes will run with the system to be developed. The business process being used is SDLC.

- Determine and gather the resources necessary data as much as possible such as books, articles and journals related to Indonesian culture and manufacture based on system Android.

\section{System Analysis}

The second stage is the analysis of the need to know what will be used to build the system. Here is the analysis of system requirements:

- Analysis Technology

Analysis of the technological tools used in the manufacture of this system is the use of Android Studio as a medium to build a system or application, in addition, researchers also use the DIA application for designing business processes in such a system design usecase diagram, activity diagram and others. Other applications needed is an application that is used as a medium Photoshop design background on the system and also the design of the icon image that will be used on the button.

\section{- Information Analysis}

In this phase, researchers conducted data collection using Method Research Library that is by collecting as much information as possible from books, article and journals related to culture and Android development application to get the required information. Moreover, the author also look for similar applications to be used as a comparison.

\section{- User Analysis}

At this stage the researchers conducted an analysis and determine that the system will be created will be used to all people of Indonesia and also to all ages ranging from children to adults.

\section{Design}

Based on the analysis, the next stage of design or design products that include:

\section{a. UML Design.}

At the design stage first thing to do is do a UML design to determine the workflow system to be created. This stage is the stage of designing a system that will be described in the form of the design of UML as follows:

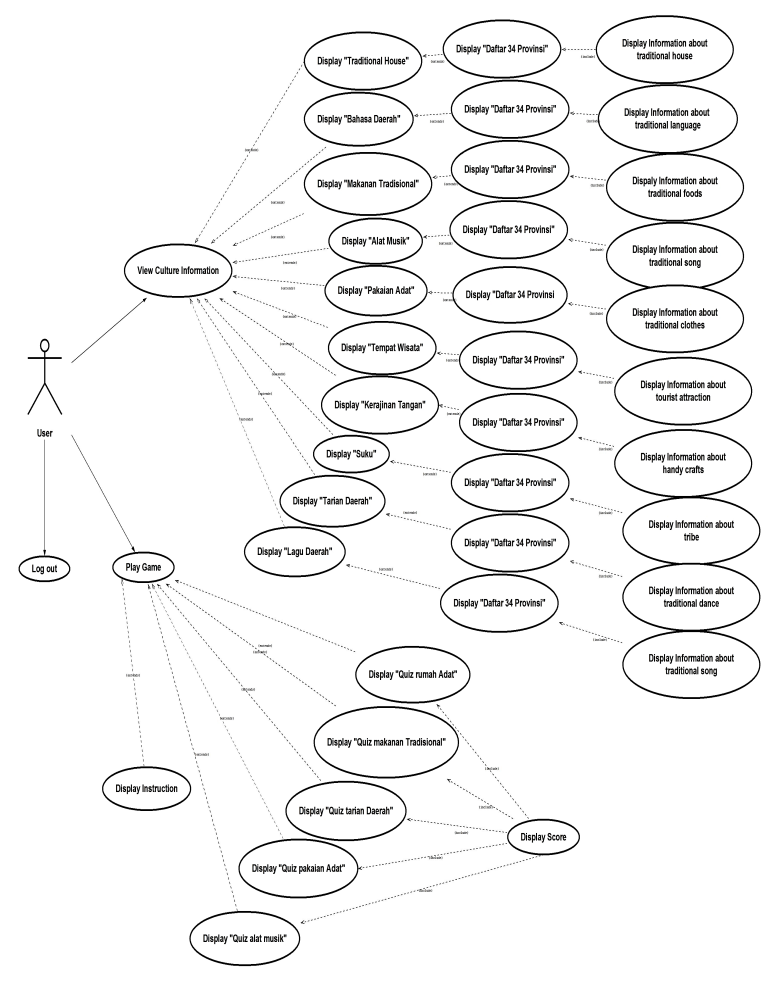

Figure 1. Use case Diagram for User

\section{Use case diagram}

Use case diagrams serve to illustrate the existing facilities within the learning system for the user. From Figure 1 Use Case Diagram for User explaining that the user gets the facility fully to open any material that is in the learning system and operate exercises are provided in the system, but the user cannot change the content of the materials and exercises since the system is still static. And of Figure 2 Use Case Diagram for Admin" explained that the admin also get the facility fully to process data and control system for the system to be updated. 


\section{ISSN 2354-0082}

i. Actor Definition

\section{- Actor (User)}

Explained about the facilities obtained by the user of the learning system of Indonesian culture. Users that is, those who have access rights to use all the facilities in the learning system that is open all cultural learning materials available, and can make or answer any exercises that exist in learning media.

\section{- $\quad$ Actor (Admin)}

Explained about the facilities obtained by the admin of the system Indonesian culture learning system. Admin that is, those who have access rights to process all the data (the learning material culture) in the system, in addition to the admin can also updating the system and to edit the layout to make it more attractive.

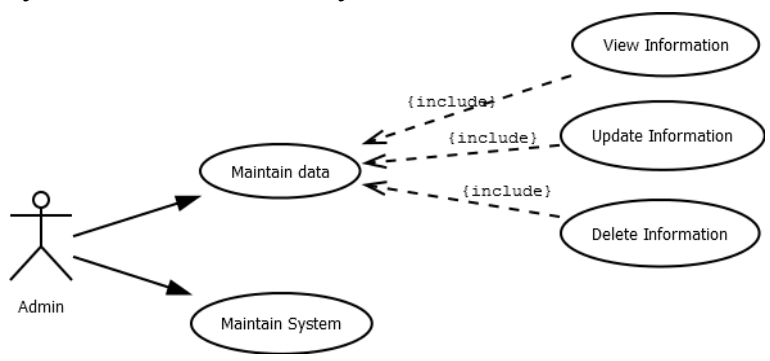

Figure 2. Use case Diagram for Admin

\section{ii. Usecase Definition}

- Use case (for User)

In this case there are three use cases that matter Indonesian Culture, exercises and exit.

1. Material Culture of Indonesia.

In this section, the user can open or view and study the material of Indonesia culture covering traditional home, traditional language, traditional food, traditional music instruments, traditional clothes, tourist attractions, crafts and traditional songs.

2. Exercises

In this section, the user can practice doing exercises by choosing the correct picture.

3. Exit

In this section, the user can log out of the system.

- Use case (for Admin)

In this case there are two Use case, which is maintaining data (material) of Indonesia culture and maintaining the system and layout.

\section{Data Maintenance (materials)}

In this section, the admin can perform data maintenance (material) such as view, update and delete data. The data in here is about traditional home, traditional language, traditional food, traditional music instruments, traditional clothes, tourist attractions, crafts and traditional songs.

\section{System Maintenance and Layout}

Admin can perform system maintenance and layout is to update the system to be compatible in all Android smartphones and admin can edit the layout of the system to make it look attractive.
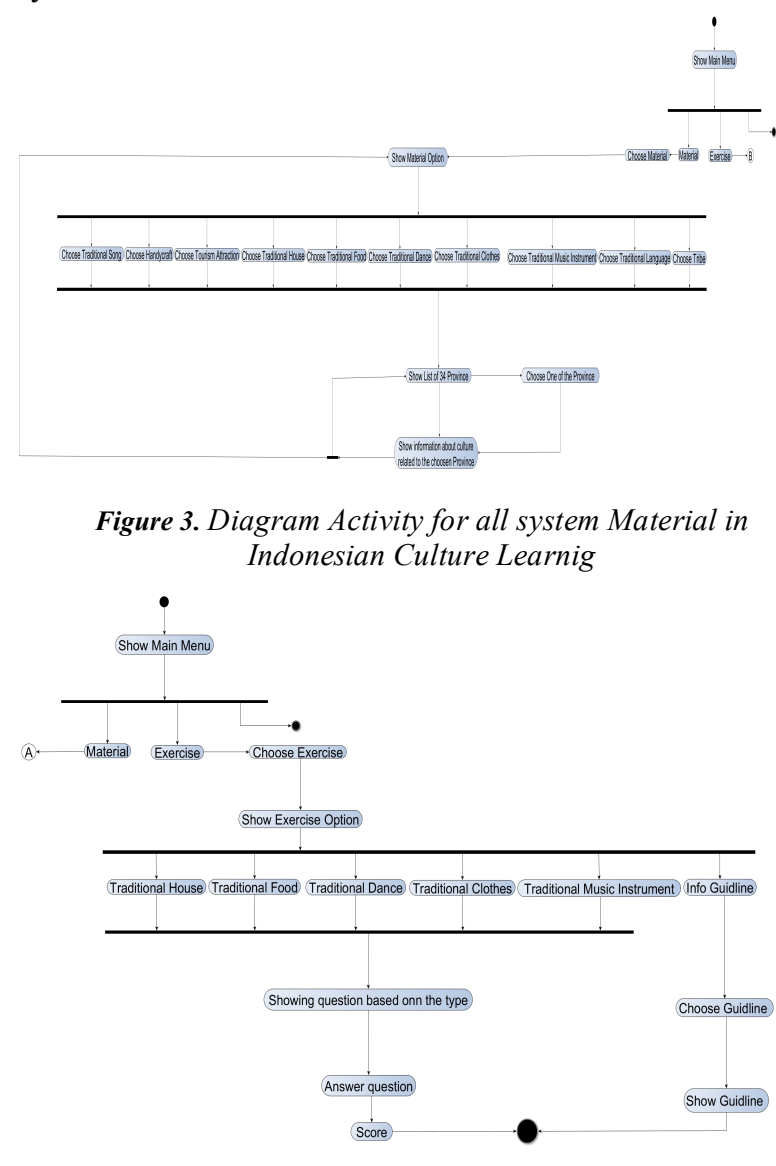

Figure 4. Diagram Activity for all system Exercise in Indonesian Culture Learnig

\section{i. Activity Diagram}

In above Figure 3 Diagram Activity for all system Material in Indonesian Culture Learning and Figure 4 Diagram Activity for all system Exercise in Indonesian Culture Learning describes that when users enter into main menu page there is a menu option Learn, Quiz and Exit. Each option has a submenu option, except the exit menu that will directly take the user out of the system. 
Here's a description from above picture of each option activity:

Table 3. Description about submenu learn and quiz

\begin{tabular}{|l|l|l|}
\hline No. & \multicolumn{1}{|c|}{$\begin{array}{c}\text { Submenu Learn } \\
\text { Option }\end{array}$} & \multicolumn{1}{|c|}{$\begin{array}{c}\text { Submenu Quiz } \\
\text { Option }\end{array}$} \\
\hline 1. & Traditional Dance & Traditional House \\
\hline 2. & Tribe & Traditional Food \\
\hline 3. & Handy Craft & Traditional Dance \\
\hline 4. & Tourist Attraction & $\begin{array}{l}\text { Traditional Music } \\
\text { Instrument }\end{array}$ \\
\hline 5. & Traditional House & Traditional Clothes \\
\hline 6. & Traditional Language & Info \\
\hline 7. & Traditional Foods & \\
\hline 8. & $\begin{array}{l}\text { Traditional Music } \\
\text { Instrument }\end{array}$ & \\
\hline 9. & Traditional Clothes & \\
\hline 10. & Traditional Song & \\
\hline
\end{tabular}

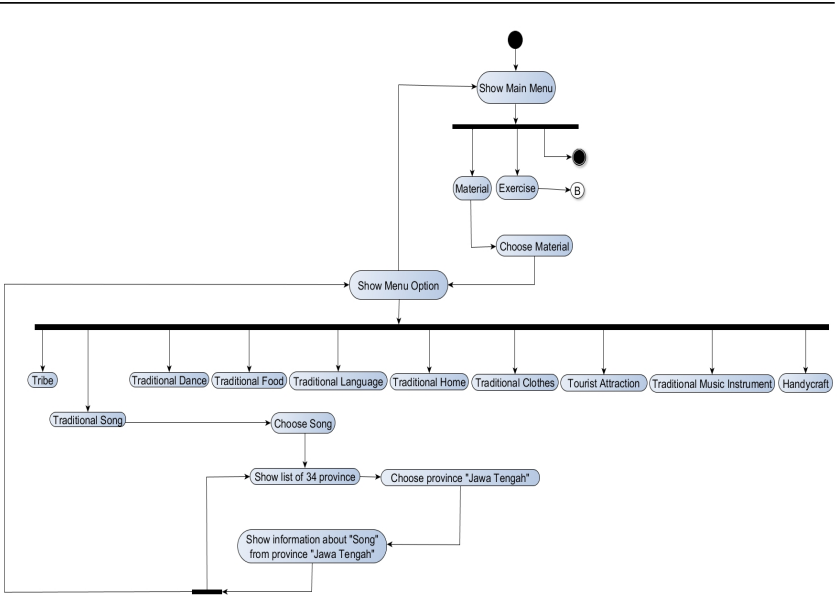

Figure 6. Diagram Activity for Song

In Figure 6 Diagram Activity for Traditional Song activity on the previous page explain that the activity begins when users are logged into the main menu page, the next activity is selecting option Learn, in option Learn there are 10 sub menu, then the user will choose a submenu Traditional Song hereinafter will be list menu of 34 provinces in Indonesia after that user will

The explanation for the menu option Learning and

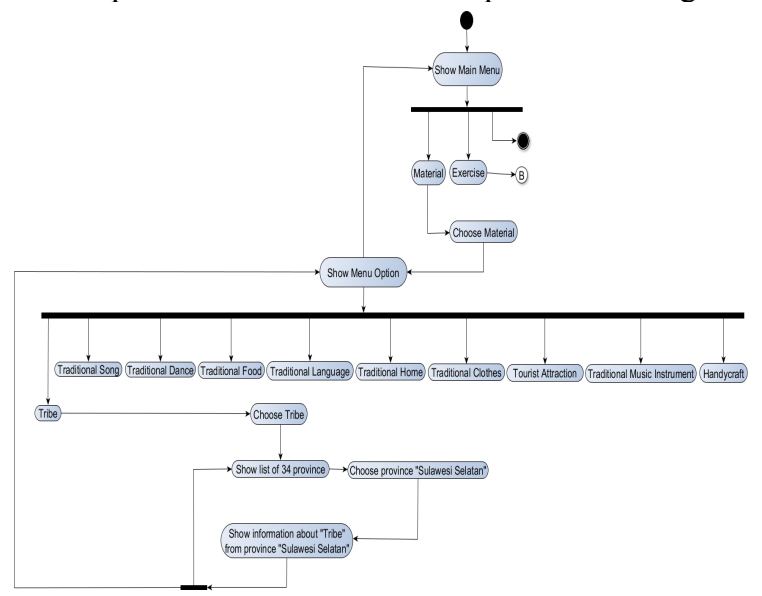

Figure 5. Diagram Activity for Tribe

submenus:

In Figure 5 Diagram Activity for Tribe on the previous page explain that the activity begins when users are logged into the main menu page, the next activity is selecting option Learn, in the option Learn there are 10 submenu, then the user will choose a submenu Tribe which subsequently will be list menu of 34 provinces in Indonesia after that user will choose one of the provinces, and after that there will be information about the tribe of the provinces selected by the user. User can see other information about tribe from another province by choosing another province on list province.

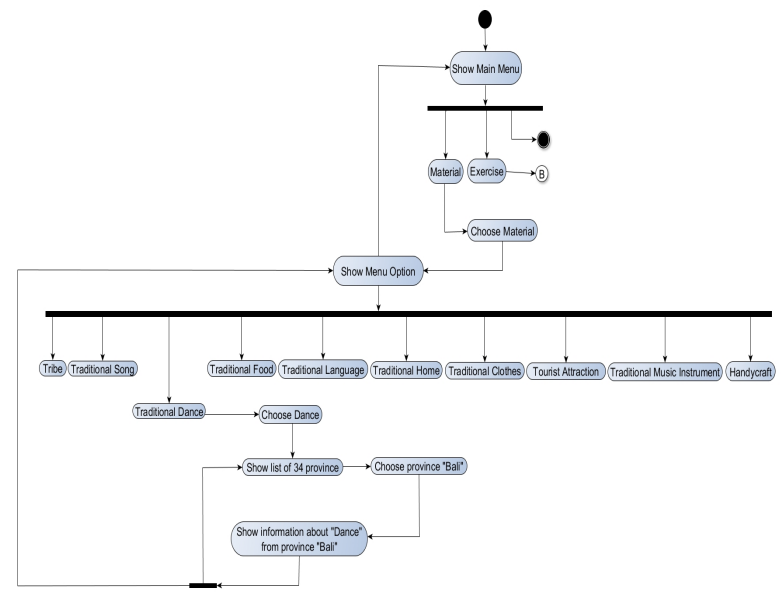

Figure 7. Diagram Activity for Traditional Dance

choose one of the provinces, and after that there will be information about the traditional song of the provinces selected by the user. User can see other information about song from another province by choosing another province on list province.

In Figure 7 Diagram Activity for Traditional Dance on the previous page explain that the activity begins when users are logged into the main menu page, the next activity is selecting option Learn, in option Learn there are 10 submenu, then the user will choose a submenu Traditional Dance which will further there list menu of 34 provinces in Indonesia after that user will choose one of the provinces, and after that there will be information about the traditional dance of the province selected by the user. User can see other information about traditional dance from another province by choosing another province on list province. 


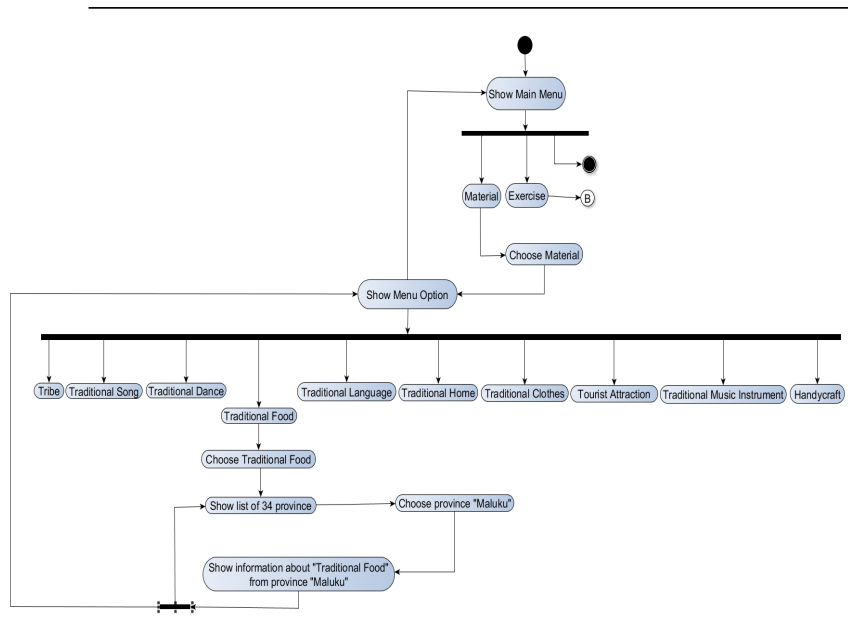

In Figure 8 Diagram Activity for Traditional Food on the previous page explain that the activity begins when users are logged into the main menu page, the next activity is selecting option Learn, in option Learn there are 10 submenu, then the user will choose a submenu Traditional Food that then there will be list menu of 34 provinces in Indonesia after that user will choose one of the provinces, and after that there will be information about the traditional food of the province selected by the user. User can see other information about traditional food from another province by choosing another province on list province.

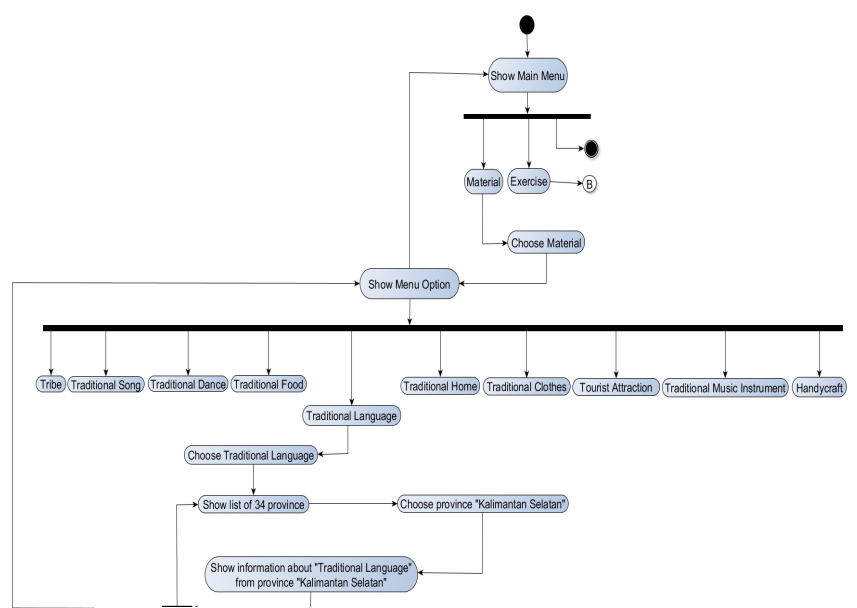

Figure 9. Diagram Activity for Traditional Language

In Figure 9 Diagram Activity for Traditional Language on the previous page explain that the activity begins when users are logged into the main menu page, the next activity is selecting the "Learn, in option Learn there are 10 submenu, then the user will choose a submenu Traditional Language hereinafter there will be list menu of 34 provinces in Indonesia after that user will choose one of the provinces, and after that there will be information about the traditional language of the province selected by the user. User can see other information about traditional language from another province by choosing another province on list province.

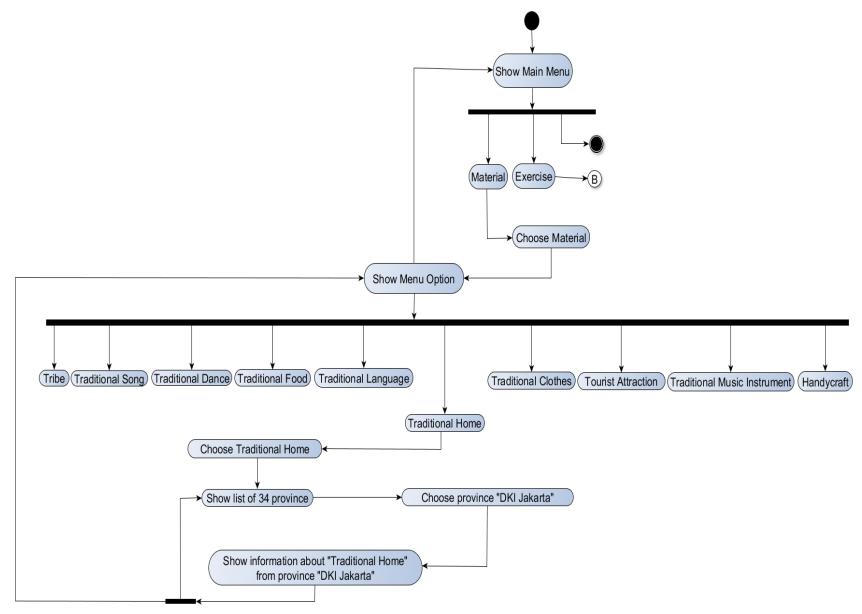

Figure 10. Diagram Activity for Traditional Home

In Figure 10 Diagram Activity for Traditional Home on the previous page explain that the activity begins when users are logged into the main menu page, the next activity is selecting option Learn, in option Learn there are 10 submenu, then the user will choose a submenu Traditional House that then there will be list menu of 34 provinces in Indonesia after that user will choose one of the provinces, and after that there will be information about the traditional house of the provinces selected by the user. User can see other information about traditional house from another province by choosing another province on list province.

In Figure 11 Diagram Activity for Traditional Clothes on the previous page explain that the activity begins when users are logged into the main menu page, the next activity is selecting option Learn, in option Learn there are 10 submenu, then the user will choose a submenu Traditional Clothes that then there will be list menu of 34 provinces in Indonesia after that user will choose one of the provinces, and after that there will be information about the traditional clothes of the provinces selected by the user. User can see other information about traditional house from another province by choosing another province on list province.

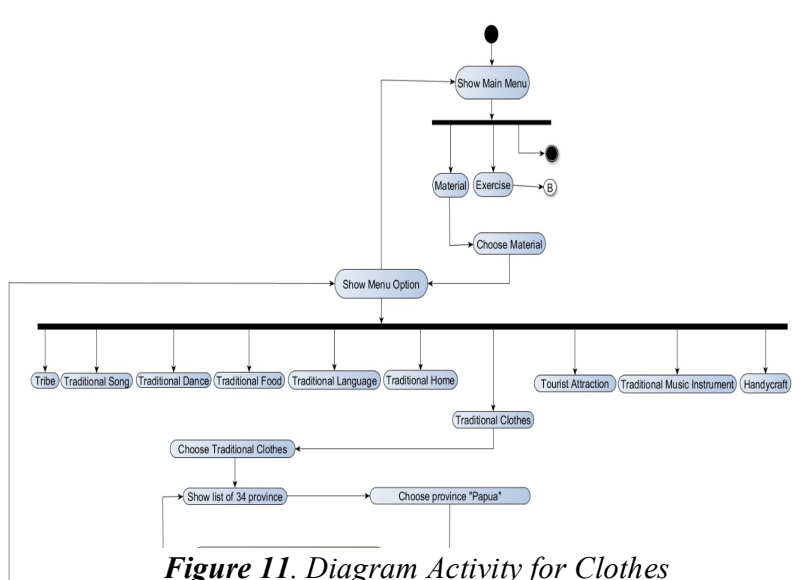

Figure 11. Diagram Activity for Clothes 


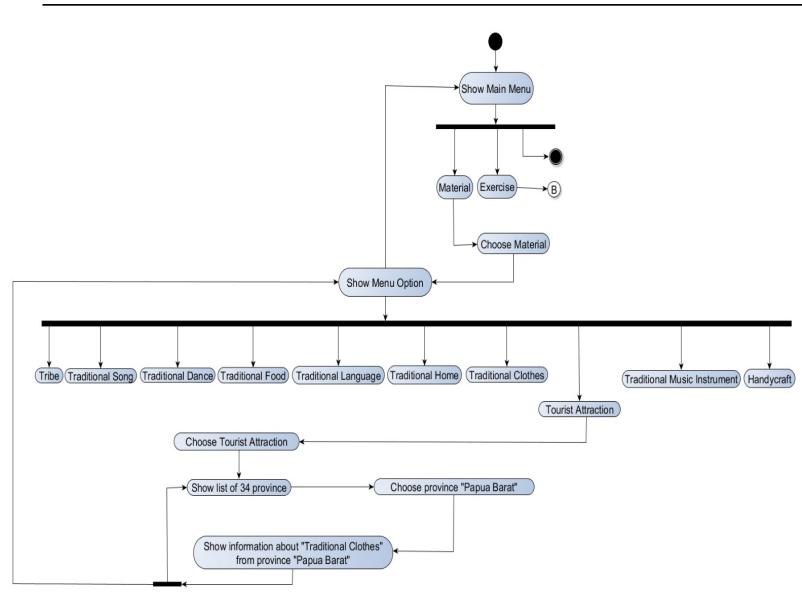

Figure 12. Diagram Activity for Tourist Attraction

In Figure 12 Diagram Activity for Tourist Attraction on the previous page explain that the activity begins when users are logged into the main menu page, the next activity is selecting option Learn, in the Learn there are 10 submenu, then the user will choose a submenu Traditional Tourist Attraction which would then be no list menu of 34 provinces in Indonesia after that user will choose one of the provinces, and after that there will be information about the traditional tourist attraction of the province selected by the user. User can see other information about traditional house from another province by choosing another province on list province.

In Figure 13 Diagram Activity for Traditional Music Instrument on the previous page explain that the activity begins when users are logged into the main menu page, the next activity is selecting the option Learn, in option Learn there are 10 submenu, then the user will choose a submenu Traditional Music Instrument which would then be no list menu of 34 provinces in Indonesia after that user will choose one of

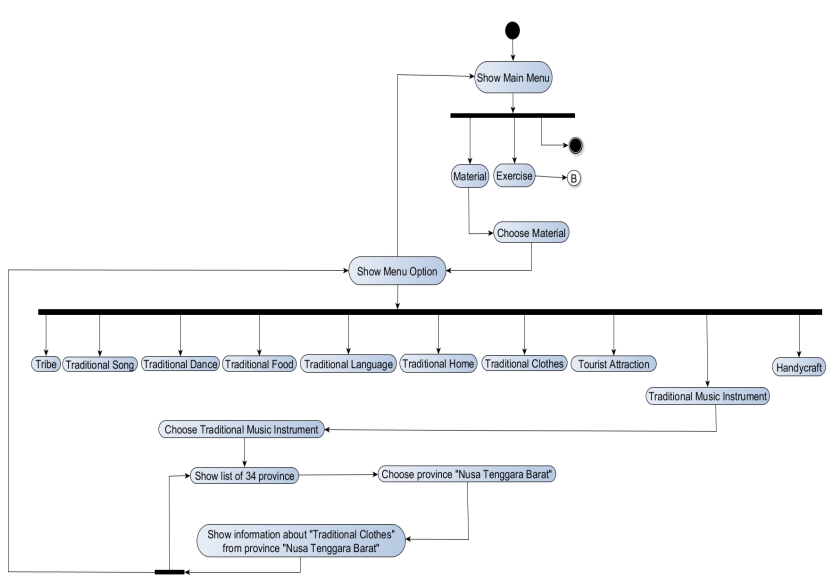

the provinces, and after that there will be information

Figure 13. Diagram Activity for exercise Traditional Music Instrument

about traditional music instrument of the provinces

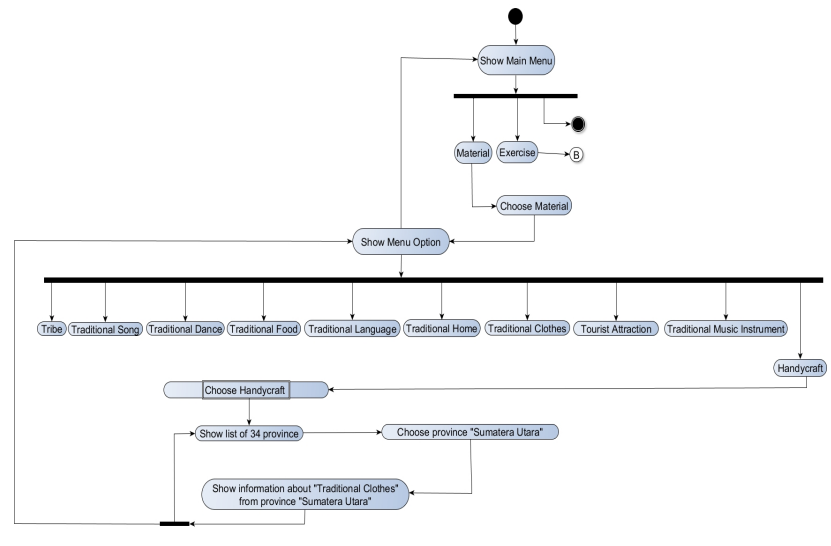

Figure 14. Diagram Activity for Handycraf

selected by the user. User can see other information about traditional house from another province by choosing another province on list province.

In Figure 14 Diagram Activity for Handy craft on the previous page explain that the activity begins when users are logged into the main menu page, the next activity is selecting option Learn, in the Learn there are 10 submenu, then the user will choose a submenu Traditional Handicraft hereinafter will be list menu of 34 provinces in Indonesia after that user will choose one of the provinces, and after that there will be information about the traditional handicrafts of the province selected by the user. User can see other information about traditional house from another province by choosing another province on list province.

The explanation for the menu option Exercise and submenu:

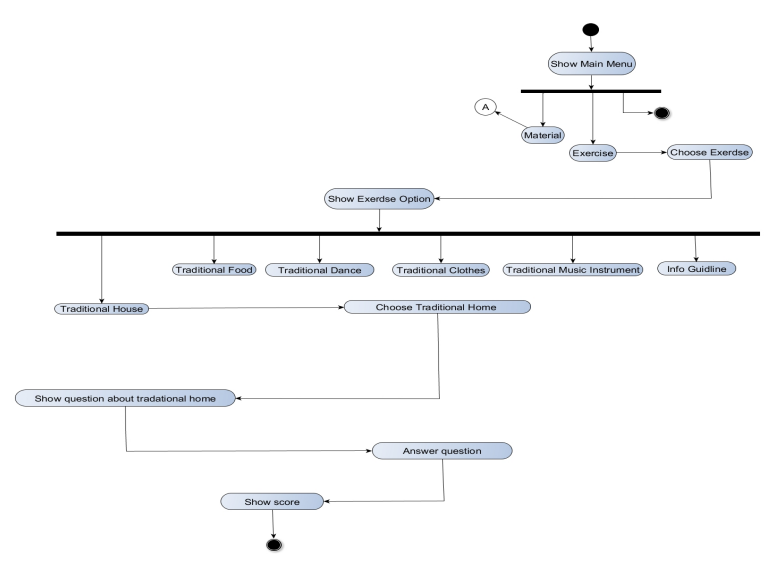

Figure 15. Diagram Activity for exercise

In Figure 15 Diagram Activity for exercise Traditional House on the previous picture explain that the activity begins when users are logged into the main menu page, the next activity is to choose Quiz, in option Quiz, there are 6 submenu, then the user will choose a submenu Traditional House which will then be there to see the question of traditional house existing 
in Indonesia after that the user will answer questions consist of 10 questions along with an image that will appear randomly and after that there will be information about scores that user obtain.

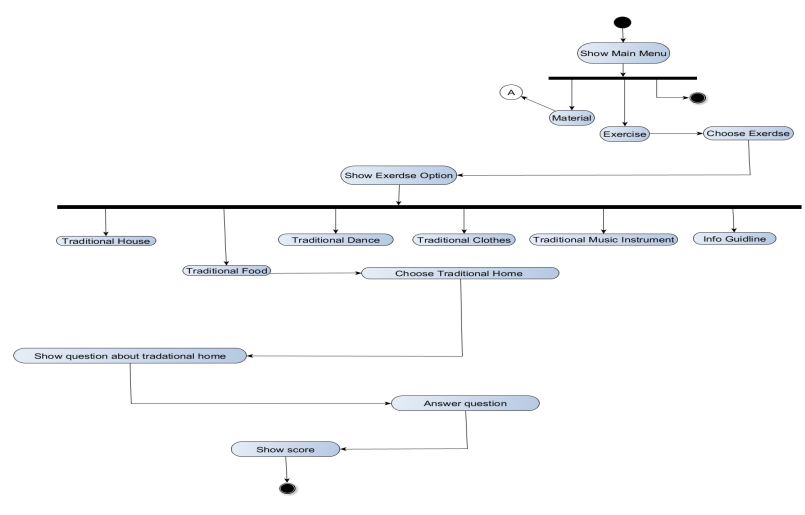

Figure 16. Diagram Activity for exercise Traditional Food

In Figure 16 Diagram Activity for exercise Traditional Food on the previous page explain that the activity begins when users are logged into the main menu page, the next activity is to choose Quiz, in option Quiz, there are 6 submenu, then the user will choose a submenu Traditional Food which in turn will be a display of questions about traditional food that is in Indonesia after that the user will answer questions consisting of 10 questions along with an image that will appear randomly and after that there will be information about scores that user obtain.

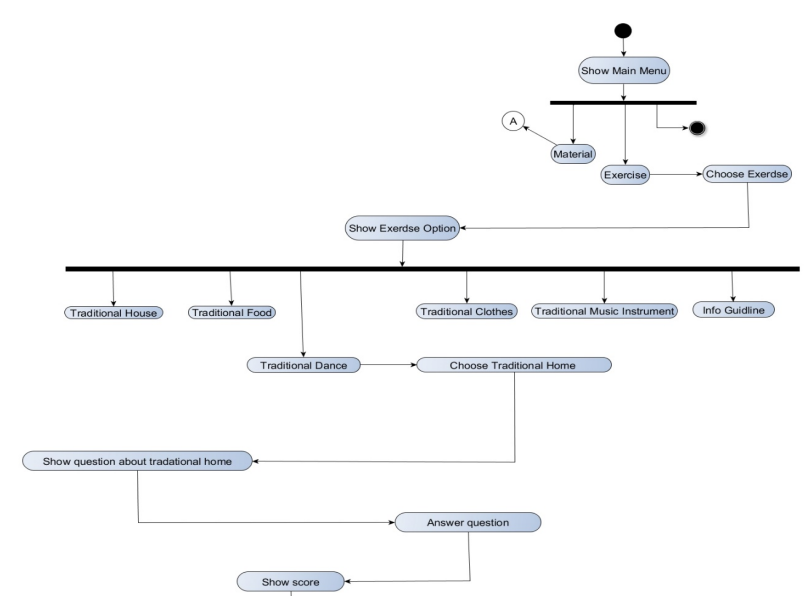

Figure 17. Diagram Activity for exercise Traditional Dance

On Figure 17 Diagram Activity for exercise Traditional Dance on the previous page explain that the activity begins when users are logged into the main menu page, the next activity is to choose Quiz, in option Quiz, there are 6 submenu, then the user will choose a submenu Traditional Dance which in turn will be a display of questions about traditional dance that is

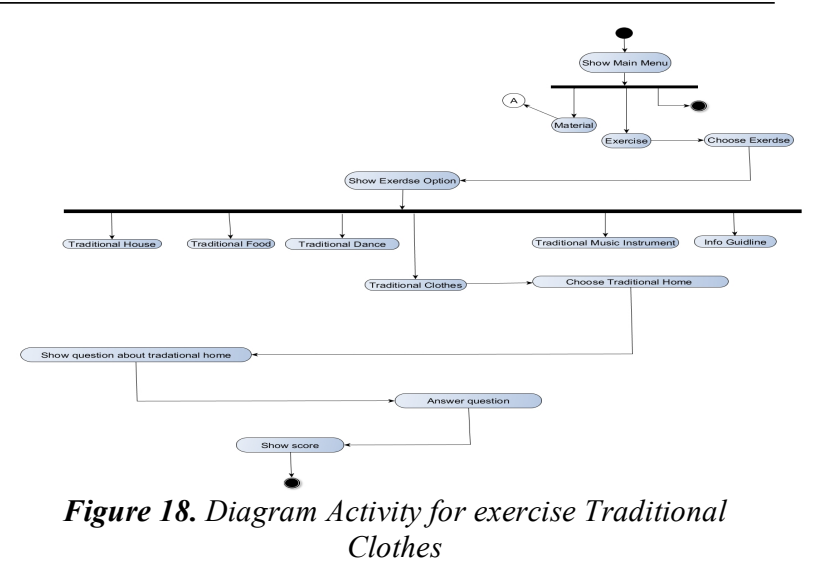

in Indonesia after that the user will answer questions consisting of 10 questions along with an image that will appear randomly and after that there will be information about scores that user obtain.

In Figure 18 Diagram Activity for exercise Traditional Clothes on the previous page explain that the activity begins when users are logged into the main menu page, the next activity is to choose Quiz, in option Quiz, there are 6 submenu, then the user will choose a submenu Traditional Clothes hereinafter will be display questions of traditional clothes that last in Indonesia after that the user will answer questions consisting of 10 questions along with an image that will appear randomly and after that there will be information about scores that user obtain.

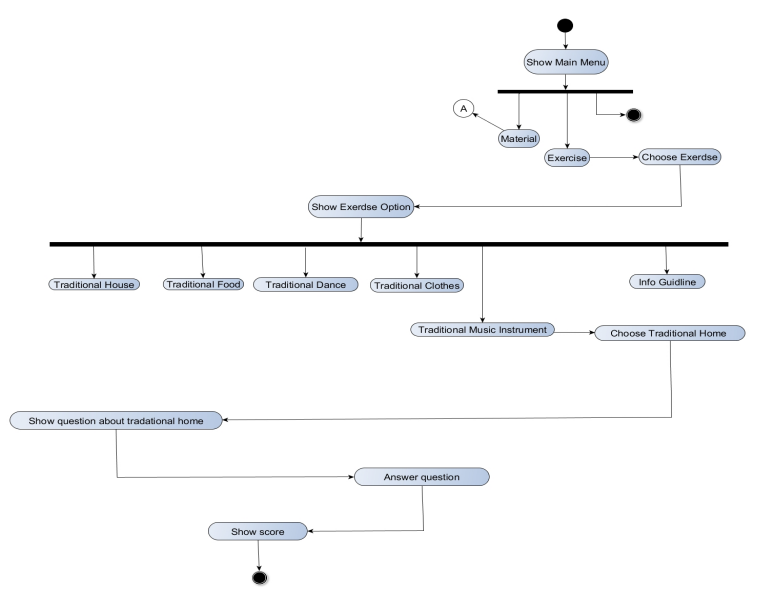

Figure 19. Diagram Activity for exercise Traditional Music Instrument

In Figure 19 Diagram Activity for exercise Traditional Music Instrument on the previous page explain that the activity begins when users are logged into the main menu page, the next activity is choose option "Quiz", in option "Quiz", there is 6 submenu, then the user will choose a submenu Traditional Music Instrument after that system will display question about traditional music instrument in Indonesia after that the user will answer questions that consist of 10 questions along with an image that will appear randomly and after that there will be information about scores that user obtain. 


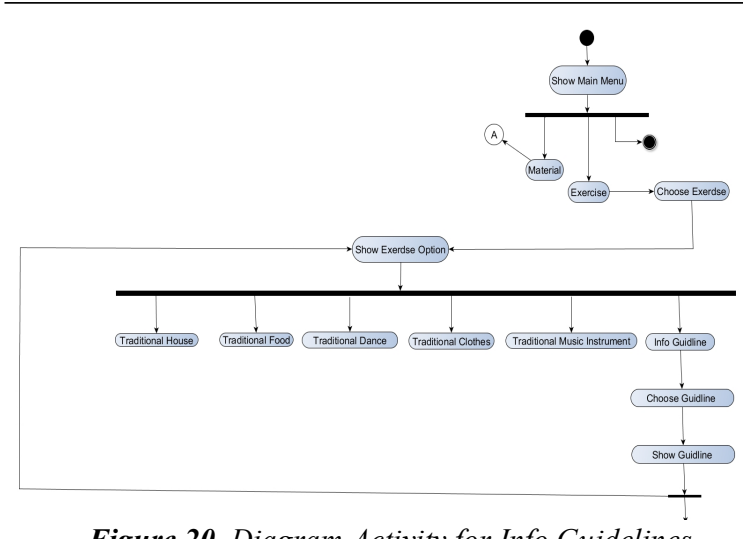

Figure 20. Diagram Activity for Info Guidelines

In Figure 20 Diagram Activity for Info Guidelines on the previous page explain that the activity begins when users are logged into the main menu page, the next activity is choose option "Quiz", in option "Quiz", there is 6 submenu, user will choose a submenu info then there will be a display information guidelines about how to answer the questions.

\section{ii. Sequence diagram}

In Figure 21 Sequence diagram for option "Belajar" on the next page explain that when the user choose option "Belajar" and the system will display 10 submenu option about culture. From 10 submenu user will choose for example option traditional house and the province is south Sumatera, the system will get data about traditional house from south Sumatera in the database after the system get valid data which is traditional house from south Sumatera, system will display the information to the user. For the other class it is also have the same sequential flow of system, which is user choose button "Belajar", the system will display submenu option about culture, user will choose the option about culture and the province, the system will get the information in database and the last is the system displaying the valid data to the user. Additional information for figure 21 sequence diagram for option "Belajar" on the figure is supposed to have 10 class about culture activity but because of all class have the same flow of sequential activity so the author only put 5 class which is MainActivity, TarianActivity, PakaianActivity, BahasaActivity, MakananActivity.

For Figure 22 Sequence diagram for quiz option on the next page explain that when the user choose button quiz, the system will display 5 submenu of quiz and info guidelines option. In the From 5 submenu of quiz user can choose one of it for example quiz about traditional foods, the system will display 10 random question about traditional foods from 34 province in Indonesia, after that the user will answer the 10 question and then the system will calculate the sore and displayed the total score that the user achieve. And the other one is when user choose option info so the system will show the information guidelines about how to answer the quiz. Additional information for figure 22 sequence diagram for quiz option on the figure is supposed to have 5 class about quiz option and 1 about info guidelines activity but because of all class of quiz option have the same flow of sequential activity so the author only put 3 class of quiz option which is Soall, Soal3, and Soal4.

\section{iii. Class Diagram}

On the Figure 23 Class diagram for Indoculture system on the next page explain that on Indoculture system there is 11 class. Each of class shown their own specification and all class are connected inside the

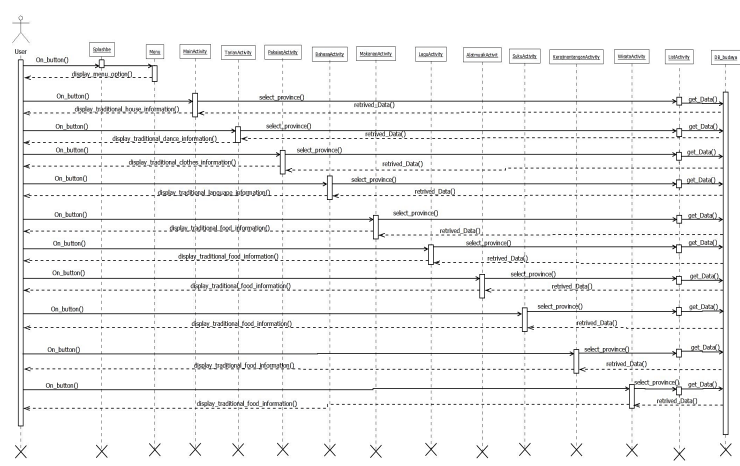

Figure 21. Sequence diagram for option "Belajar"

system. There is Db_budaya class this class has a role as database class where the other 10 classes will connected. The relationship between each of class and Db_budaya class is one to many. Db_budaya are able to create and upgrade database.

iv. Designing creative text, questions and answers

This stage is the stage where the researcher to

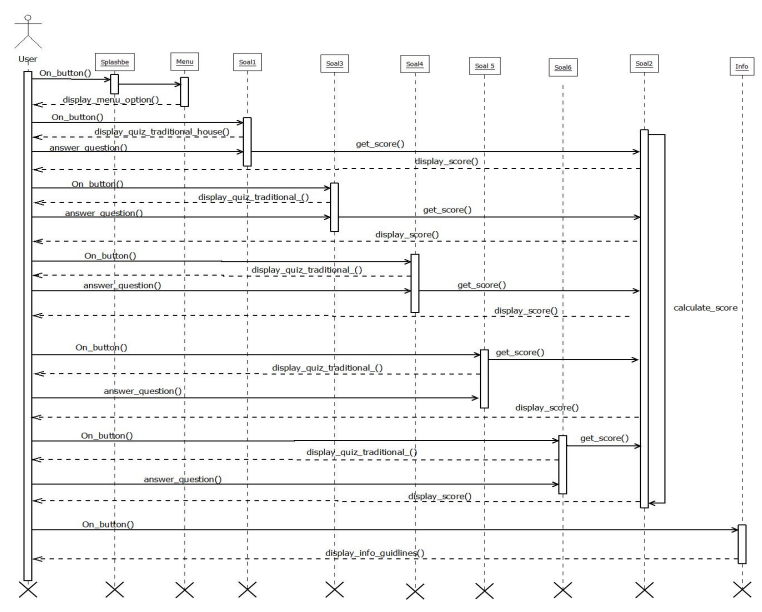

Figure 22. Sequence diagram for quiz option

review all the data that has been collected and then loaded in the format .docx (Microsoft Word document) using Microsoft word. Discussion answers will be posted in the form of image formats .png (portable 


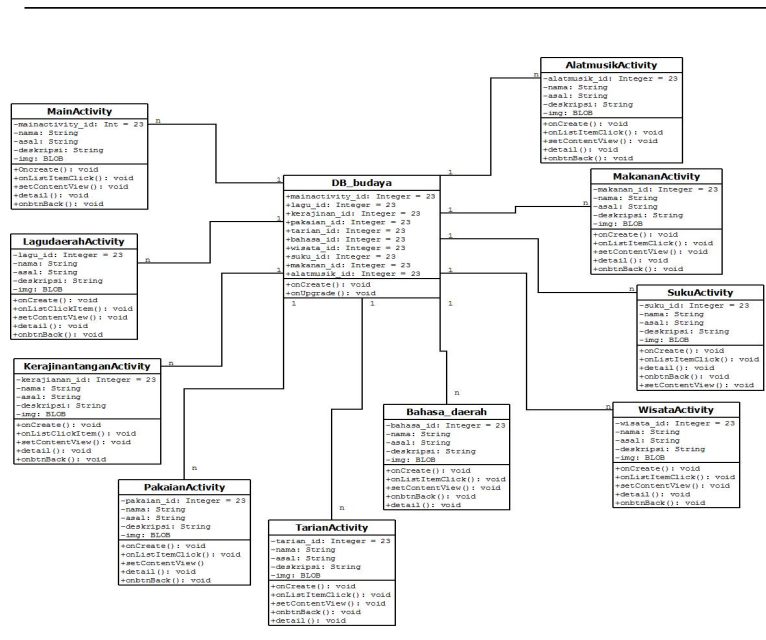

Figure 23. Class diagram for Indoculture system

network graphics) using Microsoft paint, while for manufacturing the direct question put in java.

v. Manufacture and collection background, pictures and images of icons.

The collection of drawings done by doing a search on google and then collected into one folder. Then making a background and icon images created in the image formats .png (portable network graphics) using Photoshop.

4. Implementation

a. Creating the media.

In creating the media the author using Android Studio as IDE (Integrated Developing Media). All the components that have been prepared in the design phase are then assembled into a complete media in accordance with a design that was designed before. There are three activities in the manufacture of media that is making the interface, coding and testing.

\section{b. Validation I}

At this stage the initial media validated by one media expert (lecturer) and a subject matter expert (lecturer). The result in the form of suggestions, comments, and feedback to the media that will be developed.

\section{c. Revision I}

At this stage the media will be revised based on the insert and advice provided by subject matter experts (professors) and media experts (professors).

\section{d. Validation II}

At this stage the media will be validated by the user is a student.

\section{e. Revision II}

At this stage the media will be revised based on suggestions from users enter and learning media culture in this case as a matter experts. At this stage the media will be revised and will be used in the implementation phase to the media.

\section{System Testing and Integration}

At this stage is the stage of the trial applications that have been created so that researchers can ensure that there are no errors in the application and the results should be completely in accordance with what has previously drafted, by trying the application directly using a smartphone with Android OS. Here are the list and specification of some devices which are used as emulator and tester:

$\begin{array}{lll} & \bullet \quad \text { Name } & \text { : Asus Zenfone } 5 \\ \text { OS } & : \text { Android Version 4.4.2 (KitKat) } \\ & \bullet \quad \text { Name } \quad \text { : Samsung Galaxy J1 } 6 \\ \text { OS } & : \text { Android Version 5.1.1 (Lollipop) } \\ & \bullet \quad \text { Name } \quad \text { Oppo F1s } \\ \text { OS } & : \text { Android Version 5.1 (Lollipop) } \\ & \bullet \text { Name } \quad: \text { Xiaomi 3 Pro } \\ \text { OS } & : \text { Android Version 5.1 (Lollipop) }\end{array}$

From application testing that performed on four types of smartphones with different versions of android and get satisfying results that the applications can be installed and run well on all these devices. However, there are some weaknesses that must be repaired, that is the consistency of a menu button, culture menu button position is inconsistent on the screen size of different devices. And also button back in application and back button on the device has a different function, so if pressing button back from device for example in list of province or in culture information it will not return to the previous layout but directly go to menu option.

\section{a. Field Trial}

Phase field trials media learning culture will be conducted at Tanri Abeng University south Jakarta. In this phase also distributed a questionnaire to determine student assessment regarding the media that have been made.

b. When in need of revision phase III based on feedback and suggestions from students. But in this revision will consider the feedback and suggestions from the previous validator not to conflict with previous improvements.

\section{Maintenance}

This stage is also necessary to perform maintenance such as updating android operating system on the application and update information about the culture and also updates features such as adding or removing features in applications Indoculture. 

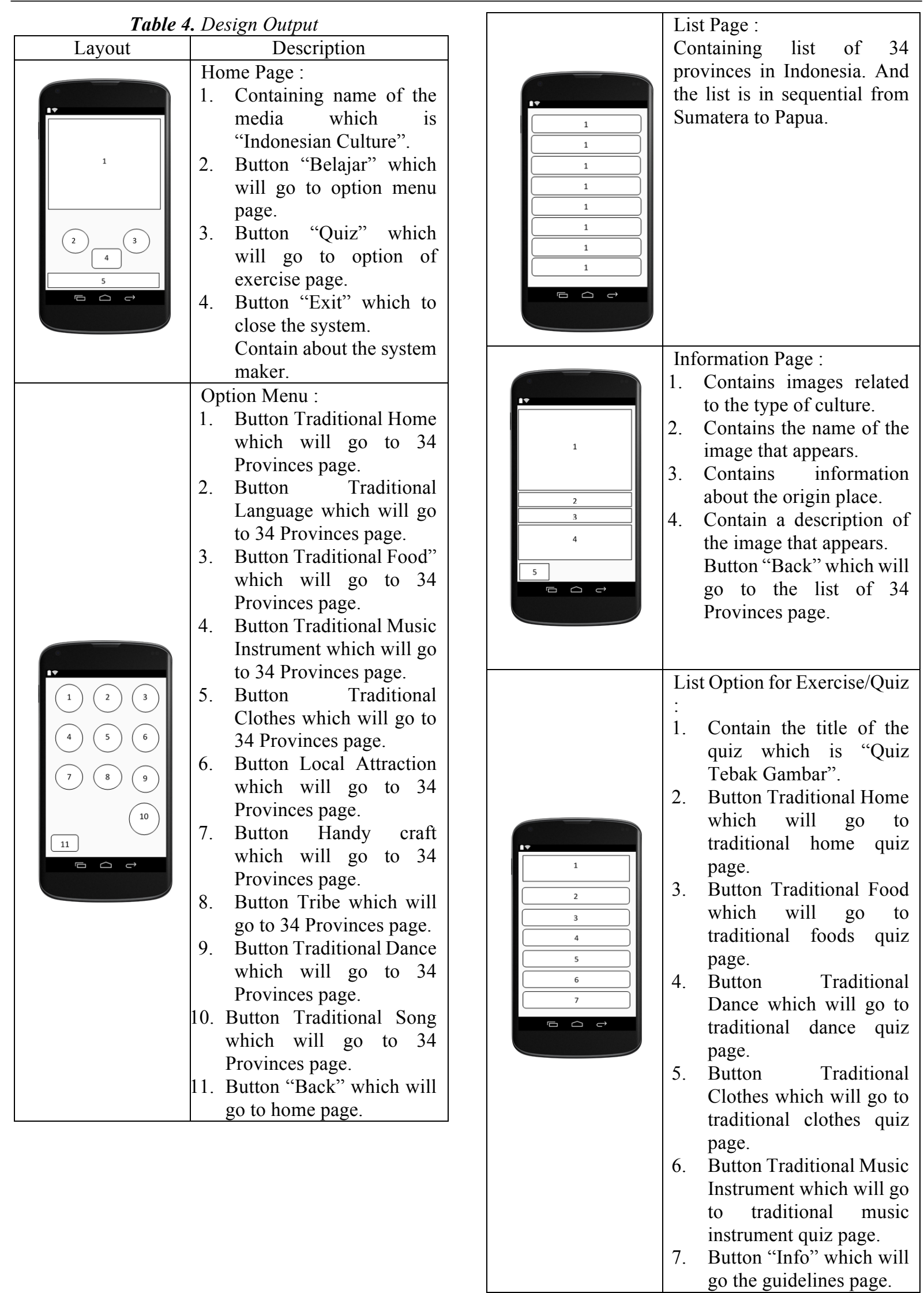


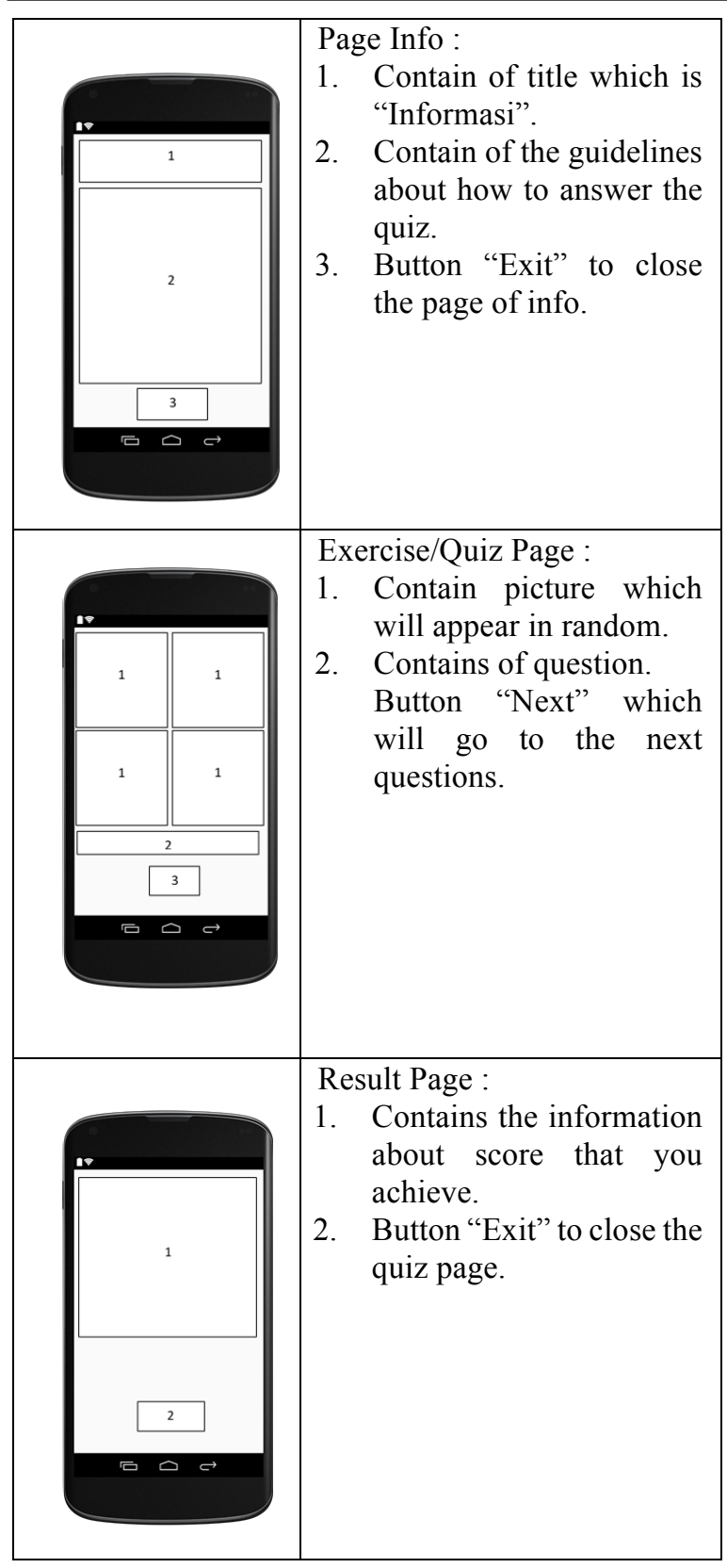

III. ANALYSIS AND DISCUSSION

\section{ANALYSIS AND DISCUSSION}

\subsection{Output of learning media}

\subsubsection{Main Display}

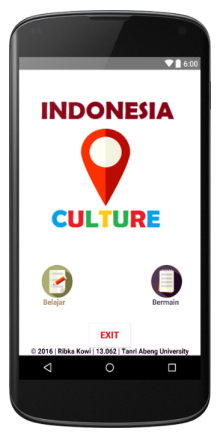

In the "Figure 3.1 Main Menu" is the result of system test on the start screen where the contents of display consists of the name of the system, information system maker and also the button "Learn" button "Quiz" and the button "Exit" third button can work very well without No debug at all.

\subsubsection{Submenu Learning Display}

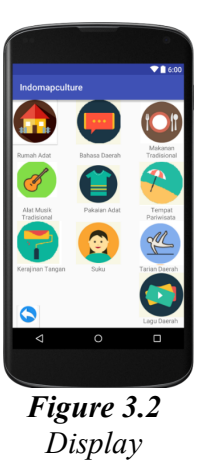

In the "Figure 3.2 Submenu Option on the Learning menu option" is the result of test systems on display submenu option on the button menu to learn where the contents of the display consists of a menu button Traditional House, Regional Languages, Traditional Food Traditional Musical Instruments, Traditional Clothes, Tourist Attraction, Crafts, Tribe, Regional Dance, and Traditional

Submenu Option on тепи "Belajar" Song tenth button can work very well with no debug at all.

\subsubsection{Display List of 34 Province}

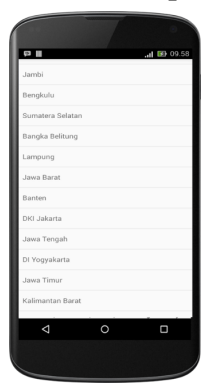

In the "Figure 3.3 Display list of province" is the result of the test system in the list view button names every province in Indonesia. Where the contents of the display consists of 34 province in Indonesia from Aceh to Papua Province. 34 list this button can work very well with no debug at all.

Figure 3.4 Display information about traditional house

Traditional House

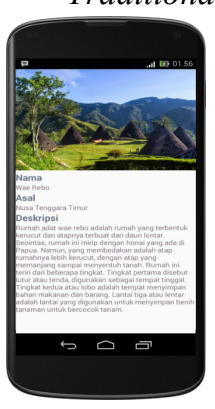

Figure 3.3 Display button list of 34 Province
3.1.4 Display Information about

On "Figure 3.4 Display information about traditional house" is a system test results on the display traditional house information content selected by province. The display consists of a traditional house name, origin province, a description of the traditional house and the back button to return to the list of province. With results like these show that in addition to the display information has gone well and the back button can work very well with no debug at all.

Figure 3.1 Main menu 


\subsubsection{Display Information about Traditional Clothes}

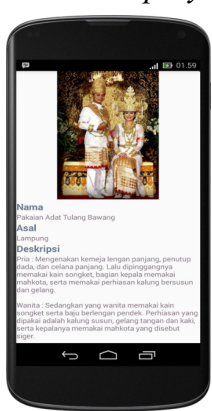

Figure 3.5

Display

information about traditional clothes

On "Figure 3.5 Display information about traditional clothes" is a system test results on the display of information content of traditional clothes selected by province. The display consists of the name of traditional clothes, provincial origin, description of the traditional clothes and a back button to return to the list of province. With results like these show that in addition to the display information has gone well and the back button can work very well with no debug at all.

\subsubsection{Display Information about Traditional Food}

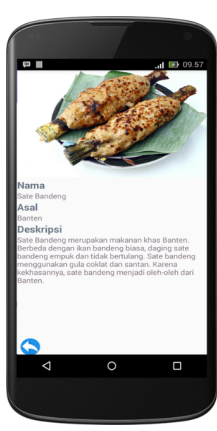

Figure 3.6 Display information about traditional food

\section{Traditional Musical Instrument}

gure 3.6 Display information about traditional food" is a system test results on the display traditional food information content selected by province. The display consists of the name of traditional food, provincial origin, description of the traditional food and the back button to return to the list of province. With results like these show that in addition to the display information has gone well and the back button can work very well with no debug at all.

\subsubsection{Display Information about}

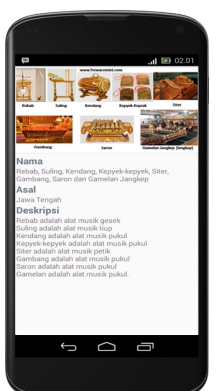

Figure 3.7 Display information about traditional music instrument

On "Figure 3.7 Display information about traditional music instrument" is a system test results on the display of information content of traditional music instrument chosen by province. The display consists of the name of traditional music instrument, provincial origin, description of the traditional music instruments and a back button to return to the list of province. With results like these show that in addition to the display information has gone well and the back button can work very well with no debug at all.

\subsubsection{Display Information about Tourist Attraction}

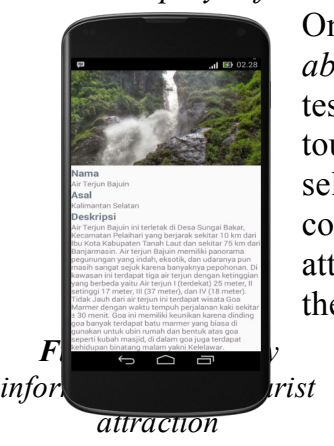

On "Figure 3.8 Display information about tourist attraction" is a system test results on a display of traditional tourist attraction information content selected by province. The display consists of a traditional tourist attraction name, province of origin, the description of the traditional tourist attraction and a back button to return to the list of province. With results like

these show that in addition to the display information has gone well and the back button can work very well with no debug at all.

\subsubsection{Display Information about Traditional Handy Craft}

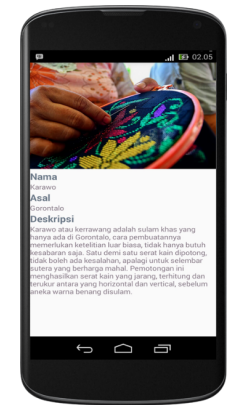

Figure 3.9 Display information about handy craft
On "Figure 3.9 Display information about traditional handy craft" is a system test results on the display handy craft traditional information content selected by province. The display consists of a handy craft traditional name, provincial origin, description of the traditional handy craft and the back button to return to the list of province. With results like these show that in addition to the display information has gone well and the back button can work very well with no debug at all.

\subsubsection{Display Information about Tribe}

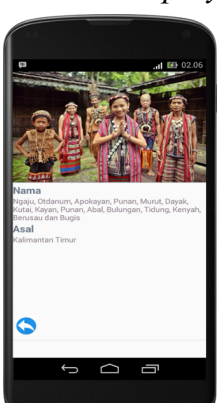

Figure 3.10 Display information about tribe

\subsubsection{Display Information about Traditional Dance}

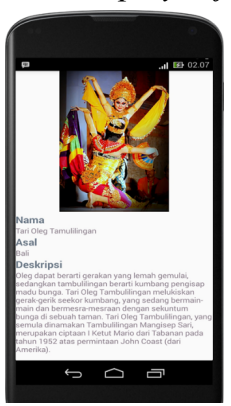

Figure 3.11 Display information about traditional dance

with no debug at all.
On "Figure 3.10 Display information about tribe" is a system test results on the display of information content tribe chosen by province. The display consists of the name of tribe, province of origin, description of the tribe and the back button to return to the list of province. With results like these show that in addition to the display information has gone well and the back.

\section{On "Figure 3.11 Display} information about traditional dance" is a system test results on a traditional dance display information content selected by province. The display consists of the name of traditional dance, provincial origin, description of the traditional dance and a back button to return to the list of province. With results like these show that in addition to the display information has gone well and the back button can work very well 
3.1.12 Display Information about Traditional Song

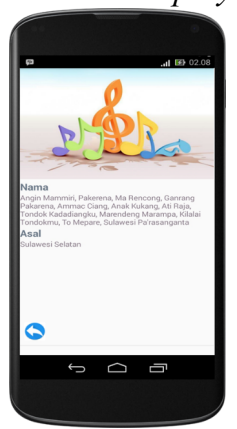

Figure 3.22 Display information about traditional song

On "Figure 3.12 Display information about traditional song" is a system test results on the display of information content of traditional song selected by province. The display consists of a traditional song name, provincial origin, description of the traditional song and the back button to return to the list of province. With results like these show that in addition to the display information has gone well and the back button can work very well with no debug at all.

\subsubsection{Display Submenu Quiz}

On "Figure 3.13 Display Submenu Quiz" is the result of test systems on display submenu quiz on the button menu quiz in which the contents of the display consists of a menu button quiz Traditional House, Traditional Food, Traditional Dance, Traditional Clothes, Traditional Musical Instruments and Info the sixth button can work very well with no debug at all.

Figure 3.13 Display Submenu Quiz

\subsubsection{Display Quiz Traditional house}

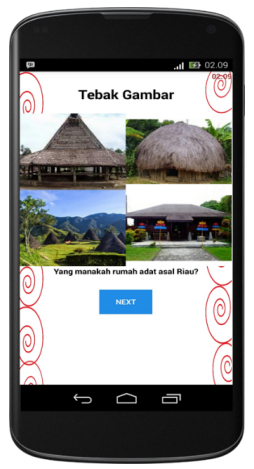

Figure 3.14 Display Quiz Traditional house On "Figure 3.14 Display Quiz Traditional house" is a system test results on the display contents of the traditional house quiz selected will appear randomly. The number of questions that will perform are as many as 10 questions. The display consists of a traditional picture house from various provinces in Indonesia, questions, and next button to go to the next question. With results like these show that in addition to the display information has gone well and the back button can work very well with no debug at all.

\subsubsection{Display Quiz Traditional Food}

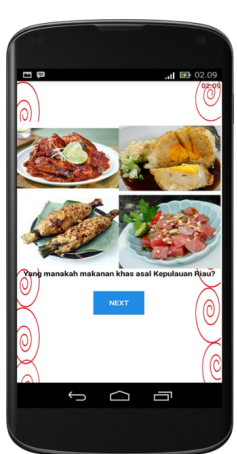

Figure 3.11 Display Quiz Traditional Food

On "Figure 3.12 Display Quiz Traditional Food" is a system test results on the display contents of a quiz about the traditional food you selected will appear randomly. The number of questions that will perform are as many as 10 questions. The display consists of a picture traditional food from various provinces in Indonesia, questions, and next button to go to the next question. With results like these show that in addition to the display information has gone well and the back button can work very well with no debug at all.

\subsubsection{Display Quiz Traditional Dance}

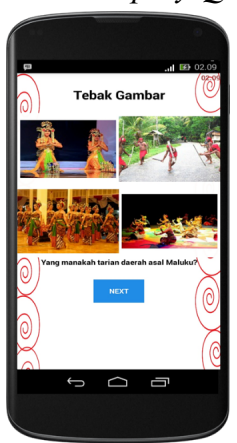

On "Figure 3.13 Display Quiz Traditional Dance" is a system test results on a display of traditional dance quiz contents selected will appear randomly. The number of questions that will perform are as many as 10 questions. The display consists of images traditional dance from various provinces in Indonesia, questions, and next button to go to the next question. With results like these show that in

Figure 3.13

Display Quiz Traditional Dance addition to the display information has gone well and the back button can work very well with no debug at all.

\subsubsection{Display Quiz Traditional Clothes}

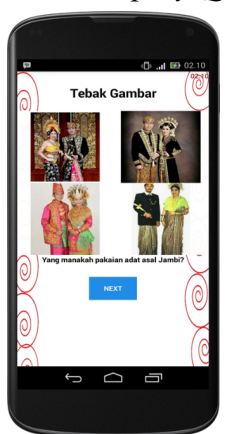

Figure 3.17

Display Quiz

Traditional

Clothes
On "Figure 3.17 Display Quiz Traditional Clothes" is a system test results on the display contents of a quiz about the traditional clothes chosen will appear randomly. The number of questions that will perform are as many as 10 questions. The display consists of images of traditional clothes of various provinces in Indonesia, questions, and next button to go to the next question. With results like these show that in addition to the display information has gone well and the back button can work very well with no debug at all.

\subsubsection{Display Quiz Traditional Music Instrument}




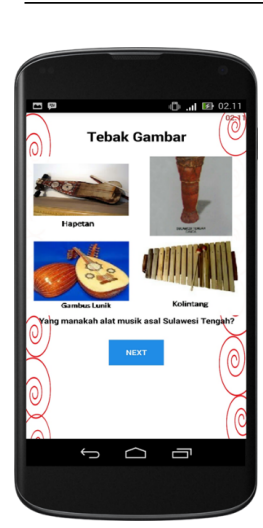

Figure 3.18Display Quiz Traditional Music Instrument
On "Figure 3.18 Display Quiz Traditional Music Instrument" is a system test results on a display of traditional music quiz content of the selected instrument will appear randomly. The number of questions that will perform are as many as 10 questions. The display consists of images of traditional music instruments from various provinces in Indonesia, questions, and next button to go to the next question. With results like these show that in addition to the display information has gone well and the back button can work very well with no debug at all.

\subsubsection{Display Info guidelines}

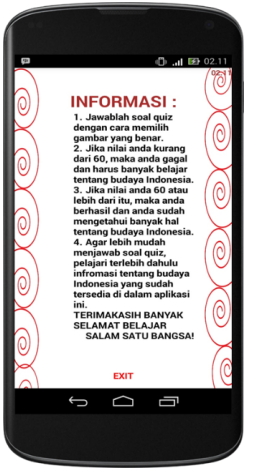

On "Figure 3.19 Display Info guidelines" is a system test results on the display guidelines on how to answer the quiz. There exit button to go to the previous page. With results like these show that in addition to the display information has gone well and the back button can work very well with no debug at all.

Figure 3.19 Display Info guidelines

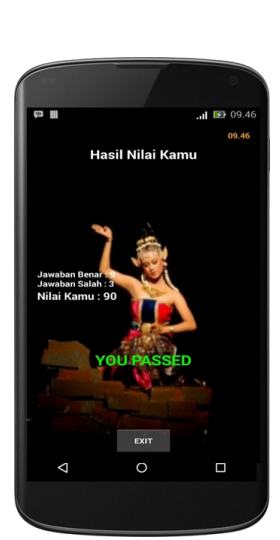

Figure 3.20 Display Score

\subsubsection{Display Score}

On "Figure 3.20 Display Score" is a system test results on the display score results have been achieved after answering the previous questions. The number of questions that will perform are as many as 10 questions. On this page will show the number of correct, wrong number and total value, if the value is less than 60 then the user fails to answer the questions correctly, if the value of 60 or more then the user has passed by answering questions correctly. With results like these show that in addition to the display information has gone well and the back button can work very well with no debug at all.

3.2 Research Result (For functionality and Usability Testing Phase)

\subsubsection{Analysis Qualitative Data}

Qualitative data are get from the questionnaire which the testers were asked to provide comments and suggestions in order to determine the advantages and disadvantages of learning to the media on the further development of this learning media will become even better. In this case the testers were very enthusiastic to give criticism and suggestions were very good and helpful for researchers. Overall criticisms and suggestions can be found in the appendix.

\subsubsection{Analysis Quantitative Data}

Implementation phase is carried out by disseminating a questionnaire to 34 students from various majors and batch in Tanri Abeng University as testers to test and assess the learning media culture that has been installed on the smartphone. The questionnaire using Likert scale with four different alternative answers according to the characteristics of the question. Besides that testers were also asked to install learning media on their smartphone. Researcher share learning media by spread link where learning media has been uploaded which is google drive and testers must download and install the learning media on their smartphones. Tester assessment results can be seen in the Appendix. In the following is the details of results of the assessment result from testers.

Table 3.2.2 Assessment Aspects and Number of values

\begin{tabular}{|c|l|c|}
\hline No. & \multicolumn{1}{|c|}{ Assessment Aspects } & $\begin{array}{c}\text { Number of } \\
\text { values }\end{array}$ \\
\hline 1. & System & 467 \\
\hline 2. & Display Media & 105 \\
\hline 3. & Displayed Information & 370 \\
\hline & Total & 942 \\
\hline & Percentage & $67,28 \%$ \\
\hline
\end{tabular}

Based on assessment results in above table 3.2.2 from the testers of Tanri Abeng University and based on assessment from the aspect of the system, display media and information displayed researcher get a total value of 942 with the percentage $67.28 \%$ which, when seen from the table of category this value included in the strong enough category that means media learning culture is quite feasible to be used as Indonesian culture learning media.

\section{CONCLUSION}

Based on the results from research and discussion before, it can be concluded as follows:

1. Based on test results "Indonesian Culture Learning Media" can be installed and run properly on smartphones with Android version KitKat and Lollipop.

2. Features in the application can run properly in accordance with user's needs which is to displays information about culture from 34 provinces in 
Indonesia such as traditional house, traditional clothes, traditional dance, traditional foods, traditional song, traditional music instrument, tourist attraction, traditional language, handy craft and tribes.

3. "Indonesian Culture Learning Media" can display 10 questions that comes with a picture that will appear randomly can run properly and also can displays the score results that user get after answering the questions in the learning media.

4. Based on the validation testing "Indonesian Culture Learning Media" by distributed a questionnaire to 34 students of Tanri Abeng University and get the average value $67.28 \%$ from the testers (students). Based on this assessment can be stated that "Indonesian Culture Learning Media" is quite decent to use as an Indonesia culture learning media.

\section{ACKNOWLEDGEMENT}

The author Ribka Kowi would like to thank to Lord Jesus because of His blessing and grace the author may finishing this Paper without any barriers, author also thank Mrs. Tri Wahyu Widyaningsih, Kom., MMS. as the supervisor who has guided the author for completing this research paper. Also thanks given to both parents who have helped in the moral and material that cannot be countless. As well as gratitude to brothers, sisters who always pray for the author and also to the loved ones who always support and help with this paper.

\section{REFERENCES}

[1] Alwan, Motea. (2015), what is system development life cycle, $\begin{array}{llll}\text { retrieved } & 19 & \text { September }\end{array}$ $<$ https://airbrake.io/blog/insight/what-is-system-developmentlife-cycle $>$.J. Clerk Maxwell, A Treatise on Electricity and Magnetism, 3rd ed., vol. 2. Oxford: Clarendon, 1892, hal.6873.

[2] Arif, Akbarul Huda. 24 JAM!! Pintar Pemrograman ANDROID, Ebook Version 2.1

[3] Arismadhani, A., Yuhana, U.L., Kuswardayan,I. (2013), Aplikasi Belajar Menulis Aksara Jawa Menggunakan Android, JURNAL TEKNIK POMITS, Vol. 2, No.2,

retrieved 2 March 2016,

$<$ http://download.portalgaruda.org/article.php?article $=88965$ $\& v a l=4186>$.

[4] DU (n.d) What is Microsoft Paint. [Online] Digital Unite. retrieved $14 \quad$ November 2016 , $<$ https://www.digitalunite.com/guides/microsoftprograms/what-microsoft-paint $>$.

[5] Elmasri, R., and Navathe, Shamkant B. (2011), Fundamentals of Database System Sixth Edition. Pearson Education,Inc.

[6] H., Nazruddin Safaat. (2012), Pemrograman Aplikasi Mobile Smartphone Dan Tablet PC Berbasis Android. Bandung: Informatika, pp. 1, 7-8
[7] Haughn, Matthew. (2015), Definition of Photoshop, retrieved $14 \quad$ November 2016, $<$ http://whatis.techtarget.com/definition/Photoshop $>$.

[8] IBM (n.d) An introduction to the Unified Modeling Language. [Online] IBM. Retrieved 14 November 2016, <http://www.ibm.com/developerworks/rational/library/7 69.html>.

[9] Imam, Dyina S., and Sismoro, Heri. (2015), Rancang Bangun Aplikasi Mobile Sebagai Media Pelestarian Lagu Traditional Dan Nasional Indonesia Berbasis Android, Jurnal Ilmiah DASI, Vol.16, No.1, retrieved 2 March 2016, $<$ https://www.google.co.id/url?sa $=$ t\&rct=j\&q=\&esrc=s\&sour $\mathrm{ce}=$ web \&cd=1\&cad=rja\&uact=8\&ved=0ahUKEwjYpozc_97 QAhULLY8KHcbZArcQFggZMAA\&url=http $\% 3 \mathrm{~A} \% 2 \mathrm{~F} \% 2 \mathrm{~F}$ ojs.amikom.ac.id\%2Findex.php $\% 2$ Fdasi $\% 2$ Farticle $\% 2$ Fview File\%2F228\%2F213\&usg=AFQjCNFbyMXtRJIXS6aIOGaA H7OsViOmxQ\&bvm=bv.139782543,d.c2I>.

[10] KKBI (n.d) Budaya. [Online] KKBI. Retrieved 14 November 2016, <http://kbbi.web.id/budaya $>$.

[11] McCann, William Jon. (2013), Dia Diagram, retrieved 14 November 2016 $<$ https://wiki.gnome.org/action/show/Apps/Dia?action=show \&redirect $=$ Dia $>$.

Murtiwiyati and Lauren, Glen. (2013), Rancang Bangun Aplikasi Pembelajaran Budaya Indonesia Untuk Anak Sekolah Dasar Berbasis Android, Jurnal Ilmiah KOMPUTASI, Vol. 12, No. 2, retrieved 2 March 2016, $<$ https://www.google.co.id/url?sa=t\&rct=j\&q=\&esrc=s\&sour ce=web\&cd=1\&cad=rja\&uact=8\&ved=0ahUKEwi6oIu_9N7 QAhWMK48KHVJmAncQFggZMAA\&url=http $\% 3 \mathrm{~A} \% 2 \mathrm{~F} \%$ 2Fmurtiwiyati.staff.gunadarma.ac.id\%2FPublications $\% 2 \mathrm{Ffile}$ s\%2F2058\%2Fjurnal\%2BAndroid.pdf\&usg=AFQjCNGipYb EnfrdkyL6XMXnI88vw0Yfnw\&bvm=bv.139782543,d.c2I $>$.

[12] Nisafani, Amna N., Muqtadiroh, Feby A., Nugraha, Nanda F. (2014), Analisis Dan Perancangan Wiki Budaya Dalam Rangka Melestarikan Budaya Bangsa Dan Kearifan Lokal Nusantara. SISFO-Jurnal Sistem Informasi, retrieved 2 March 2016, <https://www.researchgate.net/publication/280822614 $>$.

[13] Nugraha, T. S., and Tresnawati, Dewi. (2015), Pengembangan Aplikasi Pengenalan Kesenian Daerah Indonesia Sebagai Media Pembelajaran Berbasis Android. Jurnal Algoritma, Vol. 16, No.1, retrieved 2 March 2016 , $<$ http://jurnal.sttgarut.ac.id/index.php/algoritma/article/viewFi le $/ 173 / 160>$.

[14] Rizky, R. and Wibisono, T. (2015), Mengenal Seni \& Budaya 34 Provinsi di Indonesia. Jakarta Timur: Cerdas Interaktif.

[15] Sembiring, Rehulina. (2014), Panduan Android Studio, retrieved 19 September 2016, $<$ http://panduanandroidstudio.blogspot.co.id/>.

[16] Suryana. (2010), Metode Penelitian (Model Prakatis Penelitian Kuantitatif dan Kualitatif). Universitas Pendidikan Indonesia, retrieved 17 October 2016, $<$ http://file.upi.edu/Direktori/FPEB/PRODI._MANAJEMEN_ FPEB/196006021986011-SURYANA/FILE_ 7.pdf $>$.

[17] UML (n.d) The Unified Modeling Language. [Online] UML. Retrieved 14 November 2016, <http://www.umldiagrams.org/>.

[18] Valacich, Joseph S., George, Joey F., and Hoffer, Jeffrey A. (2012), Essentials of System Analysis \& Design, 6th edn, Pearson Education,Inc.

[19] Wijaya, Raden. (2015), Skala Likert (Metode Perhitungan, Persentase dan Interval, retrieved 14 November 2016, $<$ http://dokumen.tips/documents/skala-likert-metodeperhitungan-persentase-dan-interval.html\#>. 